\title{
Inhibitory effect of Newtonia extracts and myricetin-3-o-rhamnoside (myricitrin) on bacterial biofilm formation
}

Katlego E. Motlhatlego ${ }^{1,2}$, Muna Ali Abdalla ${ }^{1,3^{*}} \mathbb{D}$, Carmen M. Leonard ${ }^{4}$, Jacobus N. Eloff ${ }^{1}$ and Lyndy J. McGaw ${ }^{1}$

\begin{abstract}
Background: Diarrhoea is a major health issue in both humans and animals and may be caused by bacterial, viral and fungal infections. Previous studies highlighted excellent activity of Newtonia buchananii and N. hildebrandtii leaf extracts against bacterial and fungal organisms related to diarrhoea-causing pathogens. The aim of this study was to isolate the compound(s) responsible for antimicrobial activity and to investigate efficacy of the extracts and purified compound against bacterial biofilms.

Methods: The acetone extract of N. buchananii leaf powder was separated by solvent-solvent partitioning into eight fractions, followed by bioassay-guided fractionation for isolation of antimicrobial compounds. Antibacterial activity testing was performed using a broth microdilution assay. The cytotoxicity was evaluated against Vero cells using a colorimetric MTT assay. A crystal violet method was employed to test the inhibitory effect of acetone, methanol: dichloromethane and water (cold and hot) extracts of N. buchananii and N. hildebrandtii leaves and the purified compound on biofilm formation of Pseudomonas aeruginosa, Escherichia coli, Salmonella Typhimurium, Enterococcus faecalis, Staphylococcus aureus and Bacillus cereus.
\end{abstract}

Results: Myricetin-3-o-rhamnoside (myricitrin) was isolated for the first time from N. buchananii. Myricitrin was active against B. cereus, E. coli and S. aureus (MIC $=62.5 \mu \mathrm{g} / \mathrm{ml}$ in all cases). Additionally, myricitrin had relatively low cytotoxicity with $\mathrm{IC}_{50}=104 \mu \mathrm{g} / \mathrm{ml}$. Extracts of both plant species had stronger biofilm inhibitory activity against Gram-positive than Gram-negative bacteria. The most sensitive bacterial strains were E. faecalis and S. aureus. The cold and hot water leaf extracts of $\mathrm{N}$. buchananii had antibacterial activity and were relatively non-cytotoxic with selectivity index values of 1.98-11.44.

Conclusions: The purified compound, myricitrin, contributed to the activity of $N$. buchananii but it is likely that synergistic effects play a role in the antibacterial and antibiofilm efficacy of the plant extract. The cold and hot water leaf extracts of $\mathrm{N}$. buchananii may be developed as potential antibacterial and antibiofilm agents in the natural treatment of gastrointestinal disorders including diarrhoea in both human and veterinary medicine.

Keywords: Newtonia, Fabaceae, Diarrhoea, Antimicrobial, Cytotoxicity, Biofilm formation

\footnotetext{
* Correspondence: munalsamahoni@yahoo.com

${ }^{1}$ Phytomedicine Programme, Department of Paraclinical Sciences, Faculty of

Veterinary Science, University of Pretoria, Private Bag X04, Onderstepoort

0110 , South Africa

${ }^{3}$ Department of Food Science and Technology, Faculty of Agriculture,

University of Khartoum, 13314 Khartoum North, Sudan

Full list of author information is available at the end of the article
}

(c) The Author(s). 2020 Open Access This article is licensed under a Creative Commons Attribution 4.0 International License, which permits use, sharing, adaptation, distribution and reproduction in any medium or format, as long as you give appropriate credit to the original author(s) and the source, provide a link to the Creative Commons licence, and indicate if changes were made. The images or other third party material in this article are included in the article's Creative Commons licence, unless indicated otherwise in a credit line to the material. If material is not included in the article's Creative Commons licence and your intended use is not permitted by statutory regulation or exceeds the permitted use, you will need to obtain permission directly from the copyright holder. To view a copy of this licence, visit http://creativecommons.org/licenses/by/4.0/. The Creative Commons Public Domain Dedication waiver (http://creativecommons.org/publicdomain/zero/1.0/) applies to the data made available in this article, unless otherwise stated in a credit line to the data. 


\section{Background}

Diarrhoea is a neglected disease responsible for over 700,000 deaths annually of children under the age of five worldwide [1]. Ciprofloxacin has been used for the treatment of gastrointestinal infections, such as diarrhoea, for decades [2]. The over-prescribing and incorrect use of antibiotics commonly used to treat diarrhoea and other infections have led to global antibiotic resistance against several microbes. This has greatly impacted on the efficacy of most available antibacterial drugs [3]. Antibiotics are less effective when biofilms form because of the relative impermeability of biofilms, the variable physiological status of microorganisms, subpopulations of persistent strains, the presence of variations of phenotypes and the expression of genes involved in the general stress response [4]. Consequently, biofilms are a recognized source of recurrent, persistent or sporadic bacterial infections $[5,6]$.

The treatment of infection has become difficult because the biofilm mode of microbial growth has increased the survival strategies and resistance levels of microbes to drugs [3].

Many drugs have been developed that were originally sourced from natural products [7]. Plants contain a variety of secondary metabolites such as alkaloids, flavonoids, glycosides, phenols, saponins, steroids, terpenoids and tannins [8]. These metabolites may have individual bioactivity, or may act together synergistically to disrupt growth or pathogenic pathways of disease-causing organisms [9].

Some natural products are known to inhibit biofilm formation or preformed biofilms [3]. Plants are therefore a potential source of novel antibiofilm agents $[4,10,11]$ worthy of further investigation.

A wide variety of medicinal plants are used in southern Africa to treat gastrointestinal ailments as well as other infections. Two of these species include Newtonia hildebrandtii (Vatke) Torre and Newtonia buchananii (Baker) G.C.C. Gilbert \& Boutiqu of the family Fabaceae, which are used for the treatment of skin conditions and wounds and for an upset stomach $[12,13]$. In a previous study, the acetone and dichloromethane:methanol (1:1) extracts of the leaves and stems of the two species had very good antibacterial activity against a range of bacterial species with minimum inhibitory concentration (MIC) values as low as $0.02 \mathrm{mg} / \mathrm{ml}$ [14]. This motivated the present study where the isolation of compounds responsible for this promising activity was undertaken. Additionally, hot and cold water extracts of the two species were included to more closely replicate the traditional methods of preparation and to provide evidence to support their use in traditional medicine against stomach upsets. As biofilms are an important mechanism employed by bacteria to establish infection and avoid antibiotic activity, the organic and aqueous extracts as well as the purified compound were investigated for their ability to inhibit biofilm formation.

\section{Methods \\ Plant material and extraction}

The plant species were collected from labelled trees in the Lowveld National Botanical Garden in Nelspruit, Mpumalanga, South Africa in December 2014. Voucher specimens (PRU 122347 for $N$. hildebrandtii and PRU 122348 for $N$. buchananii) were prepared and lodged in the H.G.W.J. Schweickerdt Herbarium at the University of Pretoria (South Africa) for reference purposes.

The collected plant material was dried at room temperature in a well-ventilated room and ground to a fine powder in a Macsalab Mill (Model 2000 LAB Eriez). One gram of each plant part (leaves and stems, and in the case of $N$. buchananii also the seeds and seedpods combined) was separately extracted in $10 \mathrm{ml}$ of acetone, 1:1 MeOH-DCM (technical grade, Merck), cold distilled water, or boiling distilled water in polyester centrifuge tubes. The tubes were vigorously shaken for $30 \mathrm{~min}$ on an orbital shaker, then centrifuged at $4000 \mathrm{x} g$ for 10 min. The supernatant was filtered through Whatman No.1 filter paper before it was transferred into preweighed glass containers. This was repeated thrice on the same plant material and the solvent was removed by evaporation under a stream of air in a fume hood at room temperature to yield the dried crude extract. For isolation purposes, a similar extraction method was followed where $300 \mathrm{~g}$ of $N$. buchananii leaf material was extracted in $3000 \mathrm{ml}$ of acetone (technical grade, Merck) in a $5 \mathrm{~L}$ glass bottle. The bottle was vigorously shaken and left overnight and the supernatant was filtered through Whatman No.1 filter paper before it was transferred into pre-weighed glass containers. The extraction yield was calculated as follows:

$$
\begin{aligned}
& \text { Plant crude extraction yield }(\%) \\
& =\frac{\text { Mass of dried extract }(\mathrm{g})}{\text { Mass of plant powder extracted }(\mathrm{g})} \times 100
\end{aligned}
$$

\section{Antimicrobial assay}

The antimicrobial activity of the water extracts was determined against the following bacteria: Staphylococcus aureus (ATCC 29213), Bacillus cereus (ATCC 21366), Enterococcus faecalis (ATCC 29212), Escherichia coli (ATCC 25922), Pseudomonas aeruginosa (ATCC 27853) and Salmonella enterica subsp. enterica serovar Typhimurium (ATCC 39183). The antimicrobial activity was evaluated in terms of minimum inhibitory concentration (MIC) using a rapid broth microdilution technique with $p$-iodonitrotetrazolium violet (INT) as a growth 
indicator [15]. The INT dissolved in hot water $(40 \mu \mathrm{l}$ of a $0.2 \mathrm{mg} / \mathrm{ml}$ stock solution) was added to the wells and incubated at $37^{\circ} \mathrm{C}$ for an hour. The MIC values were recorded as the lowest concentration of the extracts that inhibited bacterial growth, as indicated by a marked reduction in colour formation. The $p$-iodonitrotetrazolium violet turns to a red-pink formazan where bacterial growth is not inhibited. The assays were repeated three times with three replicates in each assay.

\section{Cytotoxicity assay}

The cytotoxicity of the aqueous extracts against African green monkey (Vero) kidney cells was determined by the MTT [3-(4,5-dimethylthiazol-2-yl)-2,5-diphenyltetrazolium bromide] reduction assay as previously described by Mosmann (1983) [16] with slight modifications. Vero cells were maintained at $37{ }^{\circ} \mathrm{C}$ and $5 \% \mathrm{CO}_{2}$ in a humidified environment in Minimal Essential Medium (MEM) containing L-glutamine (Lonza, Belgium) and supplemented with $5 \%$ fetal bovine serum (Capricorn Scientific Gmbh, South America) and 1\% gentamicin (Virbac, RSA). These cells were seeded at a density of $10^{5}$ cells/ $\mathrm{ml}(100 \mu \mathrm{l})$ in 96-well microtitre plates and incubated at $37^{\circ} \mathrm{C}$ overnight to allow attachment. After incubation, extracts $(100 \mu \mathrm{l})$ at varying final concentrations were added to the wells containing cells. Doxorubicin hydrochloride (Pfizer) was used as a positive control. Wells made of cells in fresh medium without treatment and a blank containing only the fresh medium were used as negative controls. The plates were further incubated at $37^{\circ} \mathrm{C}$ and $5 \% \mathrm{CO}_{2}$ for $48 \mathrm{~h}$. After incubation, the medium was aspirated from the cells, which were then washed with phosphate-buffered saline (PBS). Then, $200 \mu \mathrm{l}$ fresh medium together with $30 \mu \mathrm{l}$ MTT $(5 \mathrm{mg} / \mathrm{ml}$ in PBS) were added to each well and the plates were incubated at $37^{\circ} \mathrm{C}$ in a $5 \% \mathrm{CO}_{2}$ humidified incubator for $4 \mathrm{~h}$. The medium was carefully aspirated from the wells and the formed formazan crystals were dissolved in dimethylsulfoxide (DMSO). The plates were placed on an orbital shaker for about $2 \mathrm{~min}$. The absorbance was measured on a microplate reader (BioTek Synergy) at $570 \mathrm{~nm}$. Cell growth inhibition for each extract was expressed in terms of $\mathrm{LC}_{50}$ values, defined as the lethal concentration that caused $50 \%$ inhibition of cell viability. The selectivity index (SI) values were calculated by dividing $\mathrm{LC}_{50}$ values by the MIC values in the same units $\left(\mathrm{SI}=\mathrm{LC}_{50} / \mathrm{MIC}\right)$. Tests were carried out in quadruplicate and each experiment was repeated thrice.

\section{Isolation of the compound}

$N$. buchananii was selected for isolation of antimicrobial compounds owing to the high antimicrobial activity of the crude extracts. The crude acetone extract $(43.8 \mathrm{~g})$ of $N$. buchananii was subjected to silica gel column chromatography $(7.5 \times 60 \mathrm{~cm})$, silica gel $60: 0.05-0.2 \mathrm{~mm}$, 70-270 mesh (Macherey-Nagel \& Co) eluted with $\mathrm{CH}_{2} \mathrm{Cl}_{2}$ followed by stepwise addition of $\mathrm{CH}_{3} \mathrm{OH}$ (gradient 0 to $100 \%$ ) to yield eight fractions. The antibacterial activity of the eight fractions was determined against the six bacterial pathogens known to cause diarrhoea. The next step was to isolate the bioactive compounds from the most active fraction with low cytotoxicity using Sephadex LH-20 column chromatography.

\section{Structure elucidation of the isolated compound}

The compound was characterized by means of $1 \mathrm{D}$ and 2D NMR (spectroscopic and mass spectrometry analysis. ${ }^{1} \mathrm{H}$ NMR and 2D NMR including COSY, HMQC, and HMBC data were acquired on a $400 \mathrm{MHz}$ NMR spectrometer (Bruker Avance III $400 \mathrm{MHz}$ ). HPLC-HR-ESIMS was performed on Waters Acquity Ultra Performance Liquid Chromatography (UPLC ${ }^{\bullet}$ ) system hyphenated to a quadrupole-time-of-flight (QTOF) instrument.

\section{Inhibition of biofilm formation}

The biofilm inhibition assay was determined according to Sandasi et al. (2011) [10]. In this study the various stages of biofilm development were assumed to be: no attachment/planktonic (T0), initial attachment (T4), irreversible attachment (T24) and mature biofilm (T48). The extracts were resuspended in acetone for the acetone and MeOH: DCM extracts, and sterile distilled water for water extracts and prepared to the same concentration as the MIC value ( [14], Table 1). Briefly,

Table 1 Antibacterial activity and cytotoxicity of water extracts of two Newtonia species

\begin{tabular}{|c|c|c|c|c|c|c|c|c|c|c|}
\hline \multirow[t]{2}{*}{ Plant name } & \multirow[t]{2}{*}{ Plant part } & \multirow[t]{2}{*}{ Extraction yield (\%) } & \multirow[t]{2}{*}{ Extract } & \multicolumn{6}{|c|}{ MIC in $\mathrm{mg} / \mathrm{ml}$ and test organisms } & \multirow[t]{2}{*}{$\mathrm{LC}_{50}(\mathrm{mg} / \mathrm{ml})$} \\
\hline & & & & Ec & $\mathrm{BC}$ & Ef & $\mathrm{Pa}$ & St & Sa & \\
\hline \multirow[t]{2}{*}{ Newtonia hildebrandtii } & Leaves & 27.5 & Cold water & 0.31 & 0.31 & 0.78 & 0.63 & 0.52 & 1.25 & 2.64 \\
\hline & & 32.00 & Hot water & 0.31 & 0.31 & 0.78 & 0.63 & 0.63 & 1.25 & 2.47 \\
\hline \multirow[t]{2}{*}{ Newtonia buchananii } & Leaves & 11.25 & Cold water & 0.84 & 0.31 & 0.78 & 1.25 & 0.63 & 1.25 & 2.48 \\
\hline & & 13.67 & Hot water & 0.63 & 0.16 & 0.78 & 0.63 & 0.63 & 0.63 & 2.95 \\
\hline Ciprofloxacin (MIC in ug/ml) & & & & 1.56 & 0.78 & 0.000098 & 0.00156 & 0.0063 & 0.0063 & \\
\hline
\end{tabular}

Minimum Inhibitory Concentration (MIC); concentration lethal to $50 \%$ of the cells ( $\left.\mathrm{LC}_{50}\right)$. Escherichia coli (Ec), Bacillus cereus (Bc), Enterococcus faecalis (Ef), Pseudomonas aeruginosa (Pa), Salmonella Typhimurium (St) and Staphylococcus aureus (Sa) 
$100 \mu \mathrm{l}$ aliquots of plant extracts or compound were placed into wells of a 96 well microtitre plate to prevent initial attachment. A $100 \mu$ l aliquot of standardised cultures $\left(\mathrm{OD}_{560}=0.02\right.$ equivalent to $\left.1.0 \times 10^{6} \mathrm{CFU} / \mathrm{ml}\right)$ of $P$. aeruginosa, S. Typhimurium, S. aureus, E. faecalis, E. coli or B. cereus was added into the wells and incubated (Scientific Group) at $37^{\circ} \mathrm{C}$ for $0,4,24$ and $48 \mathrm{~h}$ (i.e. T0, T4, $\mathrm{T} 24$ and T48) respectively without shaking. After the selected incubation periods (T0, T4, T24 and T48), $100 \mu \mathrm{l}$ of the extracts and the isolated compound (at the MIC values) were added at the different biofilm development stages and incubated at $37^{\circ} \mathrm{C}$ for $24 \mathrm{~h}$.

Ciprofloxacin at a concentration of $0.01 \mathrm{mg} / \mathrm{ml}$ served as a positive control for all organisms used in this study. Acetone or sterile water with bacterial cells served as negative controls. As soon as the selected incubation periods (T0, T4, T24 and T48) ended, the biofilm biomass was assayed using the modified crystal violet (CV) staining assay [17]. Briefly, the microtitre plates were washed three times with sterile distilled water and allowed to air-dry. Following this the plates were oven-dried at $60{ }^{\circ} \mathrm{C}$ for $45 \mathrm{~min}$. The wells were then stained with $100 \mu \mathrm{l}$ of $1 \%$ crystal violet and incubated at room temperature for $15 \mathrm{~min}$ after which the plates were washed three times with sterile distilled water to remove unabsorbed stain. The semi-quantitative assessment of biofilm formation was performed by adding $125 \mu \mathrm{l}$ of ethanol to de-stain the wells. A $100 \mu \mathrm{l}$ aliquot of the destaining solution was transferred to a new plate and the absorbance was measured with SoftMax Pro 6 at $590 \mathrm{~nm}$ using a microplate reader (SpectraMax M2). The experiments were performed in triplicate for each extract or compound and mean absorbance of 8 replicates for each experiment calculated. The mean absorbance of the samples was determined, and percentage inhibition calculated using the equation described below:

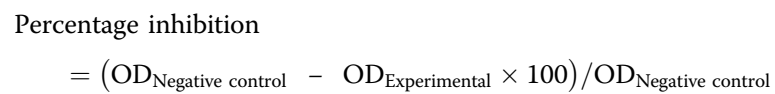

\section{Statistical analysis}

Statistical analysis was conducted with GraphPad InStat Software and results were compared using the StudentNewman
Keuls and Dunnett's tests. Data were analysed using a oneway analysis of variance to compare within each species, where there were significant differences, a Duncans Multiple Range Post Hoc test was used to separate the means. Results were considered significantly different when $P<0.05$.

\section{Results}

Minimum inhibitory concentration and cytotoxicity of the water extracts

The water extracts of $N$. hildebrandtii and $N$. buchananii had some antibacterial activity (Table 1). Although the best antibacterial effect of both water leaf extracts was against B. cereus with MIC values of $0.31 \mathrm{mg} / \mathrm{ml}$, the hot water leaf extract of $N$. buchananii had an MIC value of $0.16 \mathrm{mg} / \mathrm{ml}$. However this was not noteworthy as extracts with MIC values above $100 \mu \mathrm{g} / \mathrm{ml}$ are considered to have relatively low antibacterial activity [18]. Importantly, the extracts had SI values above 1 and as high as 18.44 (Table 2). This means that the water extracts of both Newtonia species were more toxic to the microorganisms than against mammalian Vero cells which is very promising.

\section{Characterization of the isolated compound}

The compound was isolated as a yellow powder, which produced a strong ultraviolet (UV) absorbing band on TLC at $257 \mathrm{~nm}$ and turned to yellow with vanillinsulphuric acid spray reagent. The ESI-HRMS afforded the molecular formula as $\mathrm{C}_{20} \mathrm{H}_{21} \mathrm{O}_{12}$. The molecular weight was determined by ESI-MS $(\mathrm{m} / z$ 463.0907 [M$\mathrm{H}]^{-}$, 927.1844 $\left.[2 \mathrm{M}-\mathrm{H}]^{-}\right) .{ }^{1} \mathrm{H}$ and ${ }^{13} \mathrm{C}$ NMR spectra indicated the presence of a flavonol rhamnoside. The ${ }^{1} \mathrm{H}$ NMR and ${ }^{13} \mathrm{C}$ NMR data are presented in Table 3.

\section{Minimum inhibitory concentration and cytotoxicity of the isolated compound}

The antimicrobial activity of an isolated compound is generally considered significant if the MIC is $10 \mu \mathrm{g} / \mathrm{ml}$ or lower, moderate if MIC is between 10 and $100 \mu \mathrm{g} / \mathrm{ml}$ and low if MIC is greater than $100 \mu \mathrm{g} / \mathrm{ml}[18,20,21]$. In this study it was found that myricitrin (as presented in Table 4) showed moderate activity at a MIC of $62.5 \mu \mathrm{g} / \mathrm{ml}$ against

Table 2 Selectivity index (SI) of water extracts of the selected Newtonia species

\begin{tabular}{|c|c|c|c|c|c|c|c|c|}
\hline \multirow[t]{2}{*}{ Plant name } & \multirow[t]{2}{*}{ Plant part } & \multirow[t]{2}{*}{ Extract } & \multicolumn{6}{|c|}{$\mathrm{SI}=\mathrm{LC}_{50} / \mathrm{MIC}$} \\
\hline & & & Ec & $\mathrm{Bc}$ & Ef & $\mathrm{Pa}$ & St & Sa \\
\hline \multirow[t]{2}{*}{ N. hildebrandtii } & Leaves & Cold water & 8.52 & 8.52 & 3.39 & 4.19 & 5.08 & 2.11 \\
\hline & & Hot water & 7.97 & 7.97 & 3.17 & 3.92 & 3.92 & 1.98 \\
\hline \multirow[t]{2}{*}{ N. buchananii } & Leaves & Cold water & 2.95 & 8.00 & 3.18 & 1.98 & 3.93 & 1.98 \\
\hline & & Hot water & 4.68 & 18.44 & 3.78 & 4.68 & 4.68 & 4.68 \\
\hline
\end{tabular}

Selectivity Index (SI); Escherichia coli (Ec), Bacillus cereus (Bc), Enterococcus faecalis (Ef), Pseudomonas aeruginosa (Pa), Salmonella typhimurium (St) and Staphylococcus aureus (Sa). Values in bold highlight promising SI values 
Table 3 NMR data of myricetin-3-O-rhamnoside (myricitrin, in $\mathrm{CD}_{3} \mathrm{OD}$ ) and literature data (in DMSO-d6, $500 \mathrm{~Hz}$ )

\begin{tabular}{|c|c|c|c|c|}
\hline \multirow[t]{2}{*}{ Position } & \multicolumn{2}{|l|}{ Myricitrin } & \multicolumn{2}{|c|}{$\begin{array}{l}\text { Literature data } \\
\text { (Kassem et al., 2016) } \\
{[19] \text { in }\left(\text { DMSO- } d_{6}, 500 \mathrm{~Hz}\right)}\end{array}$} \\
\hline & $\mathrm{H}$ & C & $\mathrm{H}$ & C \\
\hline 2 & & 156.4 & & 157.0 \\
\hline 3 & & 137.0 & & 134.7 \\
\hline 4 & & 181.4 & & 178.1 \\
\hline 5 & & 165.3 & & 161.7 \\
\hline 6 & $6.21, \mathrm{~d}, J=2.0 \mathrm{~Hz}$ & 99.5 & $6.20, \mathrm{~d}, J=2.0 \mathrm{~Hz}$ & 99.1 \\
\hline 7 & & 165.7 & & 165.6 \\
\hline 8 & $6.38, \mathrm{~d}, J=2.0 \mathrm{~Hz}$ & 94.3 & $6.3, \mathrm{~d}, J=2.5 \mathrm{~Hz}$ & 94.1 \\
\hline 9 & & 158.5 & & 157.8 \\
\hline 10 & & 105.7 & & 104.2 \\
\hline $1^{\prime}$ & & 123.1 & & 120.1 \\
\hline $2^{\prime}, 6^{\prime}$ & $6.96, \mathrm{~s}$ & 109.6 & $6.89, \mathrm{~s}$ & 108.4 \\
\hline $3^{\prime}, 5^{\prime}$ & & 145.7 & & 146.3 \\
\hline $4^{\prime}$ & & 136.4 & & 137.0 \\
\hline $1 "$ & $5.32, \mathrm{brd} \mathrm{s}, J=1.5 \mathrm{~Hz}$ & 102.0 & NA & 102.4 \\
\hline $2^{\prime \prime}$ & $4.23, \mathrm{dd}, J=1.6,3.3 \mathrm{~Hz}$ & 71.9 & $3.1-4.0, \mathrm{~m}$ & 71.8 \\
\hline $3 "$ & $3.79, \mathrm{dd}, J=3.6,9.6 \mathrm{~Hz}$ & 71.9 & & 70.9 \\
\hline $4^{\prime \prime}$ & $3.37, d, J=9.6 \mathrm{~Hz}$ & 73.1 & & 71.0 \\
\hline $5^{\prime \prime}$ & $3.53, \mathrm{dd}, J=6.3,9.6 \mathrm{~Hz}$ & 71.9 & & 70.4 \\
\hline $6 "$ & $0.96, d, J=6.3 \mathrm{~Hz}$ & 17.1 & $0.77, \mathrm{~d}, J=6 \mathrm{~Hz}$ & 18.0 \\
\hline
\end{tabular}

E. coli, S. aureus and B. cereus, additionally it was relatively non-toxic with an $\mathrm{LD}_{50}$ of $104 \mu \mathrm{g} / \mathrm{ml}$.

\section{Anti-biofilm potential of the extracts and the compound} The anti-biofilm activity of the Newtonia extracts, the antibacterial compound myricitrin, and the control was determined (Fig. 2). The graphs represent the biofilm inhibitory activity (BIA) of the crude extracts against some human pathogens known to cause diarrhoea.

The Gram-negative organism, $P$. aeruginosa, is a model biofilm-forming organism and BIA was evaluated at different time intervals (Fig. 2a). At time $0 \mathrm{~h}$ (organism in planktonic form) the cold water extracts of both plants enhanced the growth or biofilm development of the test organism. This enhancement was also observed at the 4 and $24 \mathrm{~h}$ timeframe and then poor inhibition of $1-40 \%$ at $48 \mathrm{~h}$ (mature biofilm). This may be due to carbohydrates dissolved by the water acting as nutrients for the bacteria. In contrast, the acetone, MeOH: DCM, and hot water extracts of both plants showed BIA of between 42 and 59\%. The leaves of N. hildebrandtii (hot water extract) showed stronger inhibition ranging from 59 to $62 \%$ at the T0, T4 and T48 biofilm formation stages. Promising activity of the water extracts indicates that $N$. hildebrandtii leaves could possibly be developed into traditional medicinal teas to treat or prevent diarrhoeal episodes if the safety can be confirmed.

Additionally, at $0 \mathrm{~h}$ biofilm against E. coli, N. hildebrandtii and $N$. buchananii acetone and $\mathrm{MeOH}$ : DCM extracts had good inhibition (Fig. 2b). Anti-biofilm activity of the water extracts of both plants showed enhancement. For the $4 \mathrm{~h}$ biofilm, $N$. hildebrandtii MeOH: DCM extract had poor BIA of $22 \%$ while all other extracts showed enhancement. The $24 \mathrm{~h}$ biofilm showed that no extract had an inhibitory effect on the attachment of $E$. coli, meaning that all extracts were enhancing growth at this time point. In the $48 \mathrm{~h}$ biofilm $N$. hildebrandtii $\mathrm{MeOH}$ : DCM and hot water extracts had poor activity of approximately $0.3-9 \%$. In contrast, the $N$. buchananii acetone leaf extract had good BIA of $55 \%$ against $E$. coli (a common diarrhoea-causing pathogen). The compound myricitrin showed excellent BIA of $84 \%$ which indicates that it may be responsible for most of the BIA in the crude extract. Furthermore, good anti-biofilm activity of myricitrin against $E$. coli was observed at all time periods (T0, T4, T24 and T48).

At $\mathrm{T} 0$, all the extracts had good BIA ranging from 57 to $\geq 100 \%$ against $S$. Typhimurium biofilm (Fig. 2c) besides the $N$. hildebrandtii cold water extract and $N$. hildebrandtii hot water extract which had poor activity and enhancement, respectively. At the $4 \mathrm{~h}$ biofilm production, all extracts resulted in enhancement. At T24 the acetone and $\mathrm{MeOH}$ : DCM extracts of both plants had BIA of approximately $16-73 \%$. The water extracts of both plants caused enhancement. At T48 the inhibition of the extracts ranged from 8 to $86 \%$. Acetone and MeOH: DCM extracts of both plants and N. hildebrandtii cold water extract had poor BIA while $N$. hildebrandtii hot water extract and $N$. buchananii cold and hot water extracts had good activity. Good anti-biofilm activity of myricitrin (above 50\%) against $S$. Typhimurium was observed at all time periods (T0, T4, T24 and T48).

Table 4 Antimicrobial activity and cytotoxicity of myricitrin from Newtonia buchananii

\begin{tabular}{|c|c|c|c|c|c|c|c|c|c|c|c|c|c|}
\hline \multirow[t]{2}{*}{ Test substance } & \multicolumn{6}{|c|}{ MIC $(\mu \mathrm{g} / \mathrm{ml})$ and test organisms } & \multirow[t]{2}{*}{$\mathrm{LC}_{50}(\mu \mathrm{g} / \mathrm{ml})$} & \multicolumn{6}{|c|}{$\begin{array}{l}\text { Selectivity index (SI) and test organisms } \\
\mathrm{SI}=\mathrm{LC}_{50} / \mathrm{MIC}\end{array}$} \\
\hline & $\overline{E c}$ & $\mathrm{Bc}$ & Ef & $\mathrm{Pa}$ & St & Sa & & Ec & $\mathrm{BC}$ & Ef & $\mathrm{Pa}$ & St & Sa \\
\hline Myricitrin & 62.5 & 62.5 & 250 & 250 & 125 & 62.5 & 104.42 & 1.67 & 1.67 & 0.42 & 0.42 & 0.83 & 1.67 \\
\hline Gentamicin & $1.56 \times 10^{-3}$ & $1.56 \times 10^{-3}$ & $9.8 \times 10^{-5}$ & $7.8 \times 10^{-4}$ & $1.5610^{-3}$ & $7.8 \times 10^{-4}$ & & & & & & & \\
\hline
\end{tabular}


The acetone, $\mathrm{MeOH}$ : DCM, and hot water extracts of $N$. hildebrandtii and N. buchananii acetone and $\mathrm{MeOH}$ : DCM extracts had inhibition ranging from approximately $33-50 \%$ in the initial attachment stage $(0 \mathrm{~h}$ biofilm) against $B$. cereus (Fig. 2d). At $4 \mathrm{~h}$ (T4) biofilm, $N$. hildebrandtii acetone and $\mathrm{MeOH}$ : DCM extracts showed enhancement while other extracts had good activity of approximately 78 to $\geq 100 \%$. In the $24 \mathrm{~h}$ biofilm, $N$. hildebrandtii $\mathrm{MeOH}$ : DCM and N. buchananii acetone extracts were below 0 while the other extracts had inhibition ranging from 1 to $58 \%$. However, all extracts had poor to very poor activity in the mature biofilm $(48 \mathrm{~h})$ and the lack of BIA may be due to the spore-forming activity of this organism as well as the complexity of the biofilm structure. Myricitrin had good activity in all biofilm stages against $B$. cereus.

In the biofilm assay against E. faecalis (Fig. 2e), at T0 the acetone and $\mathrm{MeOH}$ : DCM extracts of both plant species had good activity whilst the water extracts of both plant species enhanced growth. At $4 \mathrm{~h}$ biofilm formation, all extracts showed enhancement. At the maturation and dispersion of the biofilm ( $24 \mathrm{~h}$ and $48 \mathrm{~h}$ ), there seemed to be a similar effect. The water extracts of both plant species had very good activity of approximately 64- $\geq 100 \%$. Correspondingly, acetone extracts of both plant species had BIA of 26-50\% while $\mathrm{MeOH}$ : DCM extracts of both plant species had BIA of 1-46\%. Generally, at T24 and T48 BIA was good compared to the planktonic and attachment stages. This means that the plant extracts have the potential to overcome resistance by inhibiting biofilm formation. Myricitrin had good activity in all biofilm stages against E. faecalis.

The T0 biofilm against $S$. aureus (Fig. 2f) showed that the acetone and $\mathrm{MeOH}$ : DCM extracts of both plant species had good BIA whilst the water extracts of both plant species enhanced biofilm development. At $4 \mathrm{~h}$ and $24 \mathrm{~h}$ biofilm phases all crude extracts showed enhancement. At T48 extracts showed inhibition ranging 19$82 \%$ where $N$. hildebrandtii acetone and hot-water extracts had poor BIA of 37 and 19\%, respectively. Myricitrin had good activity in all biofilm stages against $S$. aureus.

\section{Discussion}

The antimicrobial activity of myricitrin complements the findings of the activity of the crude extract and fractions of $N$. buchananii. However, the compound had much lower antimicrobial activity than the crude extract, fractions and sub-fractions. The separation of compounds therefore leads to a decrease in activity, and increased toxicity [22]. Interestingly, the crude extracts prepared with organic solvents had very good antimicrobial activity against $P$. aeruginosa with MIC of $20 \mu \mathrm{g} / \mathrm{ml}$ [14] but the compound had low activity of $250 \mu \mathrm{g} / \mathrm{ml}$ in this study. In contrast, Aderogba and co-workers reported myricetin-3-O-rhamnoside (isolated from Croton menyharthii) to be active against E. coli and S. aureus at a much higher MIC of $250 \mu \mathrm{g} / \mathrm{ml}$ [23]. This indicates that the possible application of myricitrin would be more for its low toxicity than its moderate activity. According to Wagner and Ulrich-Merzenich (2009), synergistic effects occur if the constituents of an extract affect different targets or interact with one another to improve the solubility, thereby enhancing the bioavailability of one or several substances of an extract [24]. It is also possible that the highly active compounds were not isolated or were inactivated during the isolation procedure.

It has been established that pure drugs isolated from plants rarely have the same degree of activity as the crude extract at comparable concentrations or doses of the active component [25]. This may be due to crude extracts generally consisting of several compounds which may act synergistically with one another [21, 26]. Most traditional health practitioners recommend the use of plants as a whole rather than the isolated compounds because of this synergistic effect [27]. Our results recommend the use of $N$. buchananii leaf extract or fractions rather than a single compound for the treatment of diarrhoea as an antimicrobial agent.

The structure of myricitrin was elucidated by means of 2D spectroscopic analysis including COSY, HMQC, and HMBC (Fig. 1). A search in the Dictionary of Natural Products [28] and comparing the spectroscopic data with the literature confirmed the structure as the flavonoid myricetin-3-o-rhamnoside (myricitrin) [29]. This is the first report of isolation of the flavonoid myricetin-3-orhamnoside (myricitrin) from N. buchananii. Myricitrin has previously been isolated from Croton menyharthii, Euphorbia davidii, Myrtus communis, Pistacia chinensis, Plumbago europaea, Santaloides afzelli and Searsia chirindensis, and the compound is known for its antimicrobial, antioxidant, antigenotoxic, anti-inflammatory and antifibrotic activity [19, 30-36].

Furthermore, good anti-biofilm activity of the compound myricitrin against $P$. aeruginosa was observed at all time periods (T0, T4 and T24) with the exception of T48. Infections caused by $P$. aeruginosa may be serious and life-threatening and hard to control by most antibiotics due to its cell wall properties and ability to form biofilms [37]. Additionally, myricitrin had good antibiofilm activity against all the pathogenic strains known to cause diarrhoea that we investigated. Lopes et al. (2017) studied the inhibitory effects of the glycone myricitrin and the aglycone flavonoid myricetin, in addition to other flavonoids on biofilm formation by $S$. aureus RN4220 and S. aureus SA1199B, which are able to overexpress the msrA and norA efflux protein genes. The authors discovered that aglycone myricetin inhibited 


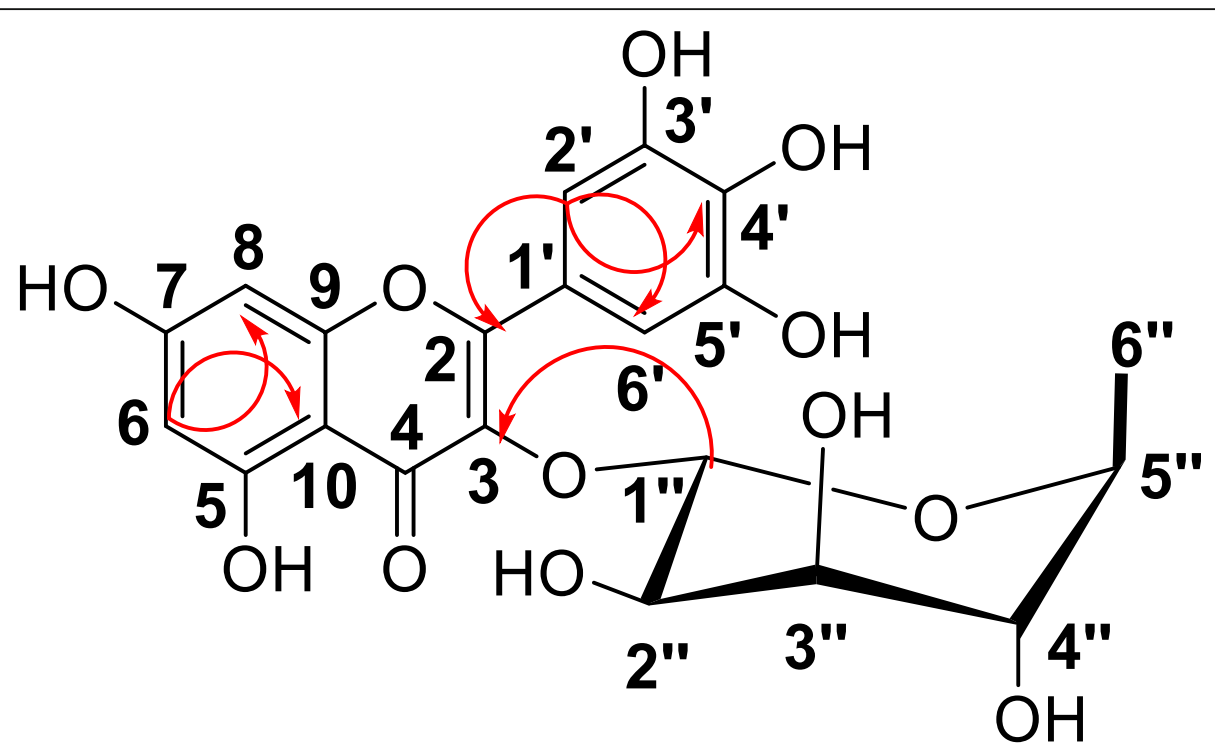

Fig. $1 \mathrm{HMBC}$ (arrows) and ${ }^{1} \mathrm{H}:{ }^{1} \mathrm{H} \operatorname{COSY}$ (bold) correlations of myricitrin

biofilm formation of $S$. aureus RN4220 and S. aureus SA1199B by $\mathrm{MBIC}_{50}$ values of 1 and $32 \mu \mathrm{g} / \mathrm{ml}$, respectively. While myricitrin exhibited $\mathrm{MBIC}_{50}$ of $128 \mu \mathrm{g} / \mathrm{ml}$ against S. aureus RN4220 and did not show biofilm inhibitory effect against S. aureus SA1199B [38]. The authors indicated that myricitrin, myricetin, and other studied flavonoids had weak inhibition on the growth of $S$. aureus strains that overexpress efflux protein genes. While sub-MICs of both myricitrin, myricetin, and other flavonoids showed inhibitory potential on biofilm formation in these strains.

The antibiofilm potential of flavonoids isolated from plants has been reported [39-41].

Moreover, recent studies investigated the inhibitory effects of plant extracts on biofilm formation and the results were in agreement with our findings, for instance, Wijesundara and Rupasinghe (2019) investigated 14 ethanol extracts of selected medicinal plants on bacterial growth and biofilm formation of Streptococcus pyogenes. The authors found that the most effective extracts had MIC and MBC of $62.5 \mu \mathrm{g} / \mathrm{mL}$ and $125 \mu \mathrm{g} / \mathrm{mL}$, respectively, while the MBIC (minimum biofilm inhibitory concentration) ranged from $31.5-250 \mu \mathrm{g} / \mathrm{mL}$ [42].

Alam et al. (2020) evaluated anti-biofilm activity of different extracts of traditionally used plants of Himalayan region of Pakistan against infectious pathogen-Pseudomonas aeruginosa PAO1. The authors suggested that various solvent extracts showed different activity against the $P$. aeruginosa PAO1 biofilm. It was found that the $1 \%$ methanolic extract of Bergenia ciliata exhibited 80\% inhibitory effect on biofilm formation without affecting the growth of the bacterium. Interestingly, the authors indicated a significant correlation in the methanolic extract between flavonoid content and anti-biofilm potential, which confirms the inhibitory effects of flavonoids against $P$. aeruginosa (PAO1) [43].

According to Sandasi et al. (2009) the enhanced biofilm development may be due to the presence of certain compounds within the crude plant extracts that provide a conditioning film promoting microbial adhesion [17]. Both plant species had anti-biofilm activity at the MIC value obtained against the planktonic stage though $N$. buchananii had more activity. The inhibition of biofilm formation may be related to the ability of this compound to inactivate microbial adhesins [44]. However, for commercial purposes it would be logical to use the active extracts. Moreover, leaves are easily accessible and traditional healers can prepare formulations using either cold water or boiling water. The dried, ground leaf powder may be soaked in hot or cold water, and the water extract can be used traditionally to relieve symptoms associated with diarrhoea. There is potential of using this plant as a tea to treat diarrhoea and related gastrointestinal conditions since the boiling hot water extract had more anti-biofilm effect than the cold water extract. The dried ground leaf powder of this plant species may be used as tea to alleviate diarrhoeal symptoms, but in vivo studies need to be conducted to confirm the useful antidiarrhoeal efficacy and lack of toxicity of this extract. The water extracts had poor antibacterial activity with MIC values above $100 \mu \mathrm{g} / \mathrm{ml}$ but had good anti-biofilm activity. This may mean that the low antibacterial activity during the planktonic stage of growth does not limit the potential of the extract to inhibit or prevent biofilm formation. As reported in Motlhatlego et al. (2018) [14] $N$. buchananii acetone and $\mathrm{MeOH}$ : DCM leaf extracts 

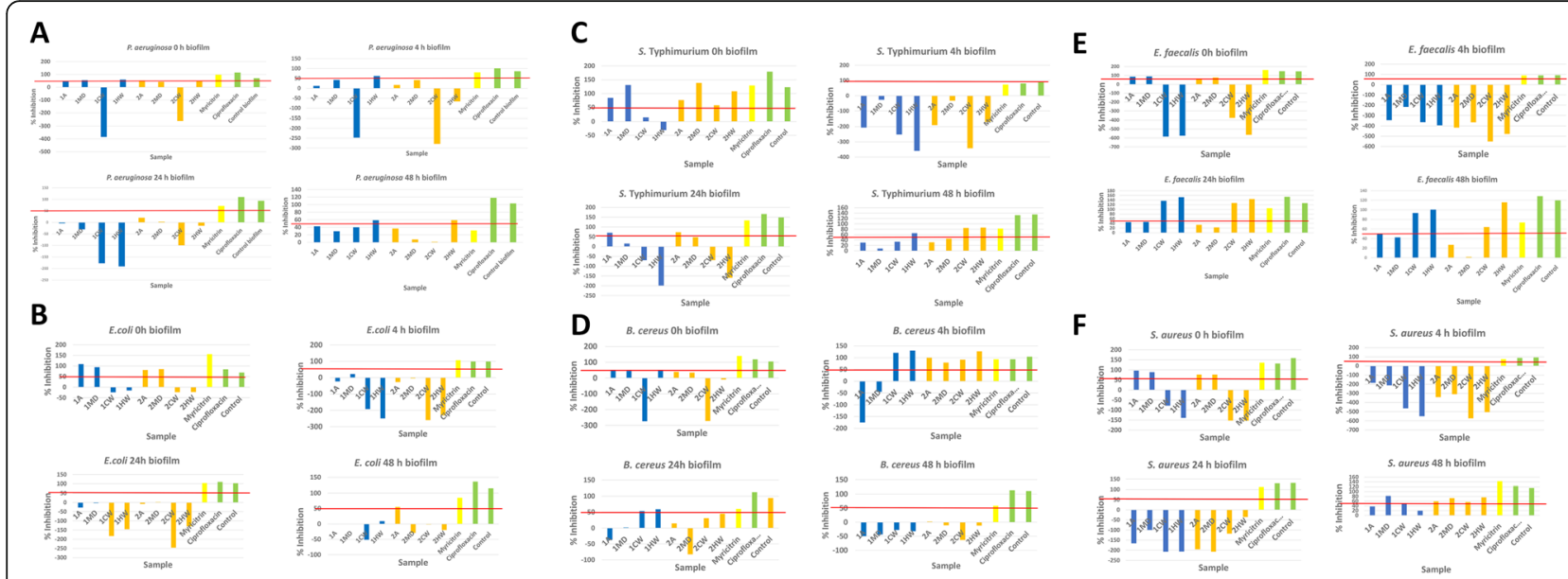

Fig. 2 0, 4, 24 and 48-h biofilm inhibition of Newtonia hildebrandtii and Newtonia buchananii extracts against bacterial strains known to cause diarrhoea. N. hildebrandtii acetone leaf extract (1A), N. hildebrandtii Methanol-DCM leaf extract (1MD), N. hildebrandtii cold-water leaf extract (1CW), $N$. hildebrandtii hot water leaf extract (1HW), N. buchananii acetone leaf extract (2A), N. buchananii MeOH: DCM leaf extract (2MD), N. buchananii cold-water leaf extract (2CW), N. buchananii hot water leaf extract (2HW)

had good antibacterial activity of $20-80 \mu \mathrm{g} / \mathrm{ml}$ against $B$. cereus, P. aeruginosa, S. Typhimurium and S. aureus. However, anti-biofilm activity at $48 \mathrm{~h}$ was only observed against $S$. aureus and $S$. Typhimurium and not the other two organisms.

Extracts of these plant species had stronger inhibitory effects against Gram-positive than Gram-negative bacteria and the most sensitive bacterial strains were $E$. faecalis and $S$. aureus. This may be because Gram-positive bacteria are more susceptible to the action of the extracts that contain flavonoids such as myricitrin [45]. Moreover, Gram-negative bacteria have a different cell wall which decreases uptake. Ciprofloxacin had very good anti-biofilm activity against all six bacteria tested in this study. Shafiei et al. (2014) emphasized the importance of determining how conventional antibiotics affect the ability of anti-biofilm agents to control biofilm perpetuation [46].

\section{Conclusion}

This study demonstrated the therapeutic significance of the flavonoid myricetin-3-o-rhamnoside (myricitrin), isolated for the first time from Newtonia buchananii, a plant used for diarrhoea, against bacterial pathogens. This flavonoid had moderate antibacterial activity against the planktonic forms of E. coli, B. cereus and $S$. aureus with MIC $=62.5 \mu \mathrm{g} / \mathrm{ml}$. This study also suggested that the leaf cold and hot water extracts of $N$. buchananii are a potential source of natural antibiofilm agents for gastrointestinal disorders, particularly diarrhoea. Biofilm formation remains a worldwide public health concern and research on the efficacy of novel molecules to prevent this formation is a priority. The antibiofilm potential of myricitrin against $P$. aeruginosa, E. coli, S.
Typhimurium, E. faecalis, S. aureus and B. cereus is a promising tool for reducing microbial colonization on surfaces and epithelial mucosa leading to gastrointestinal infections, particularly diarrhoea. Myricitrin was effective in inhibiting biofilm formation of S. aureus strains. In this study myricitrin showed a good antibiofilm dispersal effect against $S$. aureus (Fig. 2f). To the best of our knowledge this is the first report of BIA of $N$. hildebrandtii and $N$. buchananii. The development of potential antibiofilm strategies is of substantial interest. The rational next step would be to determine if there is increased synergistic effect if the two species are respectively combined with ciprofloxacin. A combination of Newtonia leaf extracts with ciprofloxacin may possibly offer a novel strategy to effectively control diarrhoeal biofilm-based infections.

\section{Abbreviations}

MIC: Minimum inhibitory concentration; MBC: Minimum bactericidal concentrations; MBIC: Minimum biofilm inhibitory concentration; MeOH: Methanol; DCM: Dichloromethane; MTT: 3-(4,5-dimethylthiazol-2-yl)2,5-diphenyltetrazolium bromide; INT: $p$-iodonitrotetrazolium violet;

SI: Selectivity index; LC 50 : 50\% lethal concentration; PBS: Phosphate-buffered saline; DMSO: Dimethylsulfoxide; BIA: Biofilm inhibitory activity

\section{Acknowledgements}

The Medical Research Council of South Africa (SIR JNE) and the National Research Foundation (Grant number 105993 to LJM) provided funding for this project. The National Research Foundation and University of Pretoria are also acknowledged for financial support via student scholarships. The curator of the Lowveld National Botanical Garden is thanked for allowing collection of plant material. Elsa van Wyk and Magda Nel of the H.G.W.J. Schweickerdt Herbarium are thanked for preparing voucher specimens.

\section{Authors' contributions}

KEM isolated the compound with the help of MAA who identified the compound. KEM performed the minimum inhibitory and cytotoxicity assays of the extracts and the compound. KEM and CML performed the inhibition of biofilm formation and crystal violet biofilm staining assay and CML provided the laboratory facilities for the biofilm work. MAA and JNE were co- 
supervisors of KEM. LJM supervised the study and provided research funding. All authors have read and approved the manuscript.

\section{Funding}

The Medical Research Council of South Africa (SIR) and the National Research Foundation (Grant number 105993) to LJM provided funding for this project. The National Research Foundation and University of Pretoria are also acknowledged for financial support via student scholarships.

\section{Availability of data and materials}

Not applicable.

\section{Ethics approval and consent to participate}

Not applicable.

\section{Consent for publication}

All authors have given their consents for publication.

\section{Competing interests}

None

\section{Author details}

${ }^{1}$ Phytomedicine Programme, Department of Paraclinical Sciences, Faculty of Veterinary Science, University of Pretoria, Private Bag X04, Onderstepoort 0110, South Africa. ${ }^{2}$ Current address: Department of Pharmacy and Pharmacology, Faculty of Health Sciences, University of the Witwatersrand, 7 York Road, Parktown, Johannesburg 2193, South Africa. ${ }^{3}$ Department of Food Science and Technology, Faculty of Agriculture, University of Khartoum, 13314 Khartoum North, Sudan. ${ }^{4}$ Microbiology Laboratory, Department of Pharmaceutical Sciences, Tshwane University of Technology, Private Bag X680, Pretoria 0001, South Africa.

Received: 4 June 2020 Accepted: 30 October 2020

Published online: 23 November 2020

\section{References}

1. World Health Organisation. Diarrhoeal disease. 2013. http://www.who.int/ mediacentre/factsheets/fs330/en/. Accessed 1 Mar 2016.

2. Pichler $H$, Diridl G, Wolf D. Ciprofloxacin in the treatment of acute bacteria diarrhoea: a double blind study. Eur J Clin Microbiol. 1986;5:241-3.

3. Ahmad I, Husain FM, Maheshwari M, Zahin M. Medicinal plants and phytocompounds: A potential source of novel antibiofilm agents. In: Rumbaugh KP, Ahmad I, editors. Antibiofilm agents; 2014. p. 205-32.

4. Namasivayam SKR, Roy EA. Anti-biofilm effect of medicinal plant extracts against clinical isolate of biofilm of Escherichia coli. Int J Pharm Pharm Sci. 2013;5:486-9.

5. Rollet C, Gal L, Guzzo J. Biofilm-detached cells, a transition from sessile to a planktonic phenotype: a comparative study of adhesion and physiological characteristics in Pseudomonas aeruginosa. FEMS Microbiol Lett. 2008;290: 135-42.

6. Lambert G, Bergman A, Zhang Q, Bortz D, Austin R. Physics of biofilms: the initial stages of biofilm formation and dynamics. New J Phys. 2014;16: 045005.

7. Newman DJ, Cragg GM. Natural products as sources of new drugs from 1981 to 2014. J Nat Prod. 2016;79:629-61.

8. Ripa FA, Haque M, Imran-Ul-Haque M. In vitro antimicrobial, cytotoxic and antioxidant activity of flower extract of Saccharum spontaneum Linn. Eur J Sci Res. 2009;30:478-83.

9. Van Wyk B-E, Wink M. Medicinal plants of the world: an illustrated scientific guide to important medicinal plants and their uses: Timber Press; 2004.

10. Sandasi M, Leonard CM, Van Vuuren SF, Viljoen AM. Peppermint (Mentha piperita) inhibits microbial biofilms in vitro. SAJB. 2011;77:80-5.

11. Abraham KP, Sreenivas J, Venkateswarulu TC, Indira M, Babu DJ, Diwakar T, Prabhakar KV. Investigation of the potential antibiofilm activities of plant extracts. Int J Pharm Pharm Sci. 2012:4:282-5.

12. Fratkin E. Traditional medicine and concepts of healing among Samburu pastoralists of Kenya. J Ethnobiol. 1996;16:63-97.

13. Kariba RM, Houghton PJ. Antimicrobial activity of Newtonia hildebrandtii. Fitoterapia. 2001;72:415-7.
14. Motlhatlego KE, Njoya EM, Abdalla MA, Eloff JN, McGaw LJ. The potential use of leaf extracts of two Newtonia (Fabaceae) species to treat diarrhoea. SAJB. 2018;116:25-33.

15. Eloff JN. A sensitive and quick microplate method to determine the minimal inhibitory concentration of plant extracts for bacteria. Planta Med. 1998:64:711-3.

16. Mosmann T. Rapid colorimetric assay for cellular growth and survival: application to proliferation and cytotoxicity assays. J Immunol Methods. 1983;65:55-63.

17. Sandasi M, Leonard CM, Viljoen AM. The in vitro antibiofilm activity of selected culinary herbs and medicinal plants against listeria monocytogenes. Lett Appl Microbiol. 2009;50:30-5.

18. Eloff JN. Quantification the bioactivity of plant extracts during screening and bioassay guided fractionation. Phytomedicine. 2004;11:370-1.

19. Kassem MES, Ibrahim LF, Husein SR, El-Sharawy R, El-Ansari MA, Hassanane MM, Booles HF. Myricitrin and bioactive extract of Albizia amara leaves: DNA protection and modulation of fertility and antioxidant-related genes expression. Pharm Biol. 2016;54:2404-9.

20. Ríos JL, Recio MC. Medicinal plants and antimicrobial activity. J Ethnopharmacol. 2005;100:80-4.

21. Awouafack MD, McGaw LJ, Gottfried S, Mbouangouere R, Tane P, Spiteller M, Eloff JN. Antimicrobial activity and cytotoxicity of the ethanol extract, fractions and eight compounds isolated from Eriosema robustum (Fabaceae). BMC Complement Altern Med. 2013;13:289.

22. Nwodo UU, Ngene AA, Iroegbu CU, Obiiyeke GC. Effects of fractionation on antibacterial activity of crude extracts of Tamarindus indica. Afr J Biotechnol. 2010;9:7108-13.

23. Aderogba MA, Ndhala AR, Rengasamy KRR, Van Staden J. Antimicrobial and selected in vitro enzyme inhibitory effects of leaf extracts, flavonols, and indole alkaloids isolated from Croton menyharthii. Molecules. 2013;18: 12633-44.

24. Wagner H, Ulrich-Merzenich G. Synergy research: approaching a new generation to phytopharmaceuticals. Phytomedicine. 2009;16:97-110.

25. Rasoanaivo P, Wright CW, Willcox ML, Glibert B. Whole plant extracts versus single compounds for the treatment of malaria: synergy and positive interactions. Malar J. 2011;10:S4.

26. Njateng GSS, Du Z, Gatsing D, Mouokeu RS, Liu Y, Zang HX, Gu J, Luo X, Kuiate JR. Antibacterial and antioxidant properties of crude extract, fractions and compounds from the stem bark of Polyscias fulva Hiern (Araliaceae). BMC Complement Altern Med. 2017;17:99.

27. Rodriguez-Fragoso L, Reyes-Esparza J, Burchiel SW, Herrera-Ruiz D, Torres E. Risks and benefits of commonly used herbal medicines in Mexico. Toxicol Appl Pharmacol. 2008;227:125-35.

28. Chapman and Hall. Dictionary of natural products on CD-ROM. Chemical DataBase; 2017

29. Elegami AA, Bates C, Gray Al, Mackay SP, Skellern GG, Waigh RD. Two very unusual macrocyclic flavonoids from the water lily Nymphaea lotus. Phytochemistry. 2003;63:727-31.

30. Hayder N, Bouhlel I, Skandrani I, Kadri M, Steinman R, Guiraud P, Mariotte AM, Ghedira K, Dijoux-Franca MG, Chekir-Ghedira L. In vitro antioxidant and antigenotoxic potentials of myricetin-3-o-galactoside and myricetin-3-orhamnoside from Myrtus commmunis: modulation of expression of genes involved in cell defence system using cDNA microarray. Toxicol in Vitro. 2008;22:567-81.

31. Serrilli AM, Sanfilippo V, Ballero M, Sanna C, Poli F, Scartezzini P, Serafini M, Bianco A. Polar and antioxidant fraction of Plumbago europaea L., a spontaneous plant of Sardinia. Nat Prod Res. 2010;24:633-9.

32. Yaya S, Benjamin KABB, Fanté B, Sorho S, Amadou TS, Jean-Marie C. Flavonoids and gallic acid from leaves of Santalloides afzelli (Connaraceae). Rasāyan J Chem. 2012;5:332-3.

33. Madikizela B, Aderogba MA, Van Staden J. Isolation and characterization of antimicrobial constituents of Searsia chirindensis L. (Anacardiaceae) leaf extracts. J Ethnopharmacol. 2013;150:609-13.

34. Domitrović R, Rashed K, Cvijanović O, Vladimir-Knežić S, Škoda M, Višnić A. Myricitrin exhibits antioxidant, anti-inflammatory and antifibrotic activity in carbon tetrachloride intoxicated mice. Chem Biol Interact. 2015;230:21-9.

35. Rédei D, Kúsz N, Szabó M, Pinke G, Zupkó I, Hohmann J. First phytochemical investigation of secondary metabolites of Euphorbia davidii Subils. and antiproliferative activity of its extracts. Acta Biol Hung. 2015;66:480-3.

36. Rashed K, Said A, Abdo A, Selim S. Antimicrobial activity and chemical composition of Pistacia chinensis Bunge leaves. Int Food Res J. 2016;23:316-21. 
37. Omwenga EO, Hensel A, Pereira S, Shitandi AA, Goycoolea FM. Antiquorum sensing, antibiofilm formation and cytotoxicity activity of commonly used medicinal plants by inhabitants of Borabu sub-county, Nyamira County, Kenya. PLoS ONE. 2017; https://doi.org/10.1371/journal.pone.0185722N.

38. Lopes LAA, dos Santos Rodrigues JB, Magnani M, de Souza EL, de SiqueiraJúnior JP. Inhibitory effects of flavonoids on biofilm formation by Staphylococcus aureus that overexpresses efflux protein genes. Microb Pathog. 2017;107:193-7.

39. Riihinen KR, OU ZM, Gödecke T, Lankkin DC, Pauli GF, Wu CD. The antibiofilm activity of lingonberry flavonoids against oral pathogens is a case connected to residual complexity. Fitoterapia. 2014;97:78-86.

40. De Souza Barboza TJ, Ferreira AE, Ignácio AC, Albarello N. Cytotoxicity, antibacterial and antibiofilm activities of aqueous extracts of leaves and flavonoids occurring in Kalanchoe pinnata (Lam.). Pers J Med Plants Res. 2016;10:763-70.

41. Faegheh Farhadi F, Khameneh B, Iranshahi M, Iranshahy M. Antibacterial activity of flavonoids and their structure-activity relationship: an update review. Phytother Res. 2019;33:13-40.

42. Wijesundara NM, Rupasinghe HPV. Bactericidal and anti-biofilm activity of ethanol extracts derived from selected medicinal plants against streptococcus pyogenes. Molecules. 2019;24(6):1165.

43. Alam K, Al Farraj DA, Fatima SM, Yameen MA, Elshikh MS, Alkufeidy, RM, Mustafa, AMA, Bhasmee, P, Alshammari, MK, Alkubaisi, NA, Abbasi AM. Naqvi TA. Anti-biofilm activity of plant derived extracts against infectious pathogen-Pseudomonas aeruginosa PAO1. J Infect Public Health. 2020. https://doi.org/10.1016/i.jiph.2020.07.007.

44. Ciocan ID, Băra II. Plants products as antimicrobial agents. Genet Mol Biol. 2007:8:151-6.

45. Evaristo FFV, Albuquerque MRJ, Dos Santos HS, Bandeira PN, Do Nascimento Ávila F, Da Silva BR, Vasconcelos AA, De Menezes Rabelo F, Nascimento-Neto LG, Arruda FVS, Vasconcelos MA, Carneiro VA, Cavada BS, Teixeira EH. Antimicrobial effect of the triterpene $3,6,16$ Trihydroxylup-20(29)-ene on planktonic cells and biofilms from Grampositive and Gram-negative bacteria. Biomed Res Int. 2014:729358.

46. Shafiei M, Ali AA, Shahcheraghi F, Saboora A, Noghabi A. Eradication of Pseudomonas aeruginosa biofilms using combination of n-butanolic Cyclamen coum extract and ciprofloxacin. Jundishapur J Microbiol. 2014;7: e14358.

\section{Publisher's Note}

Springer Nature remains neutral with regard to jurisdictional claims in published maps and institutional affiliations.

Ready to submit your research? Choose BMC and benefit from:

- fast, convenient online submission

- thorough peer review by experienced researchers in your field

- rapid publication on acceptance

- support for research data, including large and complex data types

- gold Open Access which fosters wider collaboration and increased citations

- maximum visibility for your research: over $100 \mathrm{M}$ website views per year

At BMC, research is always in progress.

Learn more biomedcentral.com/submissions 